\title{
Expressão de proteínas do corpo lúteo durante a luteogênese e luteólise induzida em éguas
}

Fernando Paixão Lisboa;, Gabriel Victoria Martins, Guilherme Novello, Raqueli Teresinha França, Ana Paula Longaray Delamare, Gabriel Fernandes Pauletti

Universidade de Caxias do Sul (UCS), Caxias do Sul, RS, Brasil

*Autor correspondente

e-mail:pxlisboa@gmail.com

\section{Resumo}

Endometrite refere-se a um processo inflamatório do endométrio que pode ser crônico ou agudo, infecioso ou não infeccioso. Na espécie equina as endometrites são consideradas uma das principais causas de queda de fertilidade, morte embrionária e abortos, gerando relevantes prejuízos econômicos. Dentre os agentes microbianos causadores de infecções uterinas na espécie equina, os mais encontrados são bactérias e fungos, sendo a endometrite bacteriana a causa mais frequente de infertilidade em éguas. A principal forma de tratamento utilizada nestes casos é a antibióticoterapia, intrauterina ou parenteral. A resistência bacteriana associada a antimicrobianos tem aumentado em função de mecanismos de sobrevivência desenvolvidos por estes patógenos e pela utilização indiscriminada de fármacos. Compostos naturais apresentam baixa probabilidade de geração ou seleção de resistência devido a sua complexidade química e forma de ação; além disso, são comuns na natureza. Este trabalho tem como objetivo testar a atividade antimicrobiana dos óleos essências de Alecrim (Rosmarinus officinalis), Carqueja (Baccharis trimera) e Capim Cidreira (Cymbopogon citratus) frente a três cepas bacterianas isoladas do útero de éguas da raça crioula, Escherichia coli (B1), Escherichia coli (B2) e Enterobacter sp. (B3). Os óleos essenciais foram obtidos através do método de extração por hidrodestilação por aparelho tipo Clevenger por uma hora (100 g de plantas desidratadas). As amostras foram colhidas de éguas crioulas com histórico de infertilidade utilizando-se coletor de swab uterino para éguas (Provar ${ }^{\circledR}$ ). Os swabs foram semeados em meios ágar sangue e Macconkey, sendo mantidas a 37º $\mathrm{C}$ por 24 horas. Após isolamento, as bactérias foram identificadas por métodos bioquímicos. A determinação do percentual de inibição (PI) para cada bactéria foi realizada através de teste de diluição em microplacas associado à leitura espectrofotométrica. Para o cálculo do PI, as leituras densitométricas das amostras com óleo foram comparadas com o crescimento na ausência deste, e expressas na forma de percentual, considerando PI superior ou igual a 90\% como concentração inibitória mínima (CIM). Foram testadas as concentrações $10 ; 5 ; 2,5 ; 1,25 ; 0,625$; 
0,3125; 0,1562; $0 \mu \mathrm{L} / \mathrm{mL}$ de óleo. Como controle positivo, foi realizado antibiograma pela técnica de difusão em disco. 0 óleo de Alecrim na concentração de $10 \mu \mathrm{L} / \mathrm{mL}$ foi o mais efetivo, apresentando PI de 98,6\%, $97,8 \%$ e $100 \%$ para as bactérias 1,2 e 3, respectivamente. Além disso, foi observado um padrão linear de inibição entre as concentrações testadas deste óleo. 0 óleo de carqueja, na mesma concentração, apresentou PI de $40,5 \%, 57,5 \%$ e 55,6\%, enquanto o óleo de capim cidreira apresentou 75,7\%, 59\% e 77,6\% para as bactérias 1, 2 e 3, respectivamente. As três bactérias testadas foram sensíveis a Sulfametoxazol + Trimetropim, Gentamicina e Amicacina. A B1 apresentou sensibilidade intermediária para Ampicilina e Ceftriaxona, a B2 para Ampicilina, enquanto a B3 apresentou resistência à Ampicilina. Tais achados comprovam que o óleo de Alecrim demonstrou superioridade em relação aos antibióticos que obtiveram sensibilidade intermediária ou resistente. 0 conjunto de resultados permite concluir que óleo de alecrim possui propriedades antibacterianas, demonstrando potencial para inibir o crescimento de bactérias causadoras da endometrite em éguas. Além disso, os demais óleos testados também apresentam potencial inibitório, entretanto as concentrações testadas não foram suficientes para atingir a CIM.

Palavras-chave: Fitoterápicos. Óleos essenciais. Alecrim. 